\title{
PEŁNA NATURA LUDZKA CHRYSTUSA W ŚWIETLE ORYGENESOWSKIEJ KONCEPCJI CZŁOWIEKA
}

Od czasów apostolskich pisarze wczesnochrześcijańscy podkreślali, że Chrystus łączy w sobie Bóstwo i człowieczeństwo, chociaż początkowo nie ujmowali tej idei w precyzyjne teologiczne sformułowanie o dwóch pełnych, ściśle ze sobą zjednoczonych naturach. Ojcowie apostolscy używali w odniesieniu do Jezusa zamiast słów „człowiek” czy „człowieczeństwo”, synonimicznego wobec nich terminu „ciało”, dla podkreślenia realności sfery cielesnej przeciw doketyzmowi ${ }^{1}$. „Explicite” o człowieczeństwie Chrystusa mówili, jako jedni z pierwszych, Tacjan i Meliton z Sardes. Dla pierwszego z nich historyczny Jezus to „Bóg w postaci człowieka” ${ }^{2}$, dla drugiego - zgodnie z prostą formułą wiary - Chrystus to „człowiek, bo jest pogrzebany, a Bóg - bo zmartwychwstaje"3. Pierwsze ślady refleksji nad integralnością natury ludzkiej Zbawiciela znajdujemy natomiast u Justyna i Ireneusza. Autor Apologii nauczał, że „Słowo stało się Chrystusem, który się dla nas objawił, czyli ciałem, Słowem i duszą" . Podobnie autor Adversus haereses wiązał zbawcze pośrednictwo Jezusa z pełnią jego człowieczeństwa: „Trzeba było, aby Ten, który miał zgładzić grzech i wykupić człowieka zasługującego na śmierć, stał się tym samym, co tenże człowiek" . Na przełomie II i III w. na Zachodzie kwestia połączenia w Chrystusie prawdziwego i kompletnego człowieczeństwa z Bóstwem została podjęta z większą precyzją przez Tertuliana. Twierdził on, że tak jak człowiek nie może istnieć bez jedności duszy i ciała, tak też w Chrystusie znajdują się te dwa elementy, chociaż jako zwolennik stoicyzmu pojmował duszę również jako subtelną postać materii ${ }^{6}$. Dodawał również z naciskiem, że dla zbawienia czło-

${ }^{1}$ Ignacy Antiocheński głosił, ze Chrystus jest „Bogiem przychodzącym w ciele” (Ad Ephesios 7, 2). Podobnie Pseudo-Barnaba twierdził, że „Syn Boży objawił się w ciele” (Epistula Barnabae 5 , $6 ; 5,10 ; 7,3 ; 12,10)$.

${ }^{2}$ Oratio ad Graecos 21, 1, PG 6, 852 C.

${ }^{3}$ Homilia de Pascha 9, SCh 123,64; Por. tamże, 7-8.

4 Apologia secunda 10, 1-3, PG 6, 462, POK 489.

${ }^{5}$ Adversus haereses III 16, 6.

${ }^{6}$ Por. De carne Christi 13, 4. 
wieka Jezus ,musiał przyjąć naszą duszę, to znaczy duszę o takiej samej formie jak nasza"7.

Pierwszą próbę syntezy nauki o pełnym człowieczeństwie Chrystusa, o strukturze jego natury ludzkiej i jej funkcjach, podjął na Wschodzie współczesny Tertulianowi Orygenes (185-253/4). Stanowiło to ewenement w środowisku aleksandryjskim, przywiązanym raczej do kontemplacji bóstwa Chrystusa i modelu chrystologii odgórnej. Jak zawsze w wypadku pionierów, nie była to próba bezwzględnie udana, niemniej jednak wystarczająco spójna i kompletna, wziąwszy pod uwagę fakt powstawania dopiero spekulatywnej teologii.

Współcześni badacze omawiający orygenesowską naukę o wcieleniu Chrystusa skupiali dotąd uwagę głównie na funkcjach Jego duszy ludzkiej ${ }^{8}$. Tymczasem równie interesujące jest to, co Orygenes mówi o duchu i ciele Zbawiciela, oraz na jakie napotyka trudności. Zanim przejdę do szczegółowego omówienia struktury człowieczeństwa Chrystusa w ujęciu autora Contra Celsum, przedstawię najpierw w zarysie jego naukę o pełnej naturze ludzkiej Jezusa, ściśle zjednoczonej z Boską - po raz pierwszy tak wyraźnie i precyzyjnie sformułowaną we wczesnochrześcijańskiej teologii - oraz przypomnę podstawowy model antropologiczny odnoszony przez Orygenesa do każdego człowieka, a więc także do ludzkiej natury Zbawiciela.

1. Chrystus - pełen Bóg i pełen człowiek. Orygenes jako pierwszy wśród autorów chrześcijańskich używa w odniesienia do Chrystusa złożonego określenia „Bóg-człowiek” ( $\theta \varepsilon$ có $-\alpha ̊ v \theta \varrho \omega \pi o \varsigma, ~ d e u s-h o m o)^{9}$. Po raz pierwszy nazywa też człowieczeństwo Jezusa wprost naturą ( $\phi \dot{\sigma} \sigma \iota \varsigma$, natura $)^{10}$, podczas gdy Tertulian określał je jako „stan” (status) lub „substancję” (substantia), posiadającą określone właściwości (proprietates). W obrazowych detalach Aleksandryjczyk

7 Tamże, 10, 3, CCL 2, 893.

8 Tak czyni M. Fédou w swoim najnowszym zarysie orygenesowskiej chrystologii, do którego niejednokrotnie odwołuję się w niniejszym artykule (La sagesse et le monde. Le Christ d'Origène, Paris 1995, 153-163), a także A. Grillmeyer, Le Christ dans la tradition chrétienne. De l'age apostolique à Chalcedoine (451), Paris 1973, s. 197.

${ }^{9}$ Por. De principiis II 6, 3, SCh 252, 314: ,[...] nascitur Deus homo [...]”. Por. uwagi H. Crouzela o thumaczeniu tego zwrotu z greckiego oryginału: SCh 253 , s. 175 , n. 18. Orygenes dał w ten sposób pierwsze tak wyraźne sformułowanie doktryny znanej później jako ,communicatio idiomatum", uznającej, że to, co przypisuje się Słowu Bożemu, należy równocześnie stwierdzić o jego człowieczeństwie i odwrotnie; zob. Origenes, Homiliae in Ezechielem 3, 3, SCh 352, 130, ŹMT 16, 104.

${ }^{10}$ Por. Contra Celsum III 28, SCh 136, 69, tłum. S. Kalinkowski: Przeciw Celsusowi, Warszawa 1986, 155; De principiis I 2, 1, SCh 252, 110, ŹMT 1, 67; tamże, II 6, 2, SCh 252, 313, ŹMT 1, 176. Nie jest w tym do końca konsekwentny, ponieważ w Commentarius in Ioannem XVIII, 107

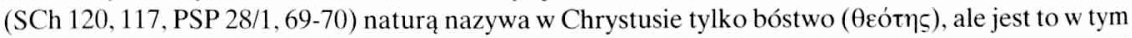
wypadku zależne od kontekstu, gdyż natura ma tu znaczenie ả@xฑ่, czyli zasady, istotnej części osoby Jezusa, która przyjmuje człowieczeństwo. 
podkreśla, że natura ludzka Zbawiciela obejmuje pełnię rzeczywistego człowieczeństwa:

„[...] potęga Boskiego majestatu, owo Słowo i Mądrość Boga [...] ogołociła się, [...] stała się człowiekiem i przebywała między ludźmi. [...] zawarla się w ograniczonych rozmiarach człowieka (intra circumscriptionem hominis), który pojawił się w Judei, [...] zstąpiła w łono kobiety, urodziła się jako niemowlę i płakała tak, jak płaczą niemowlęta. [...] dostrzegamy w Chrystusie pewne cechy ludzkie do tego stopnia, że nie różnią się one niczym od niedoskonałości wspólnej wszystkim śmiertelnikom (quaedam in eo ita videamus humana, ut nihil a communi mortalium fragilitate distare videantur $)^{\prime \prime 11}$.

Orygenes podkreśla, że sam Chrystus zwraca uwagę na swoje pełne człowieczeństwo, nazywając siebie „Synem Człowieczym”, a więc narodzonym prawdziwie, jak każdy człowiek ${ }^{12}$. Nasz autor ukierunkowuje interpretację tego określenia antydoketystycznie, stwierdzając w różnych miejscach swych pism, że trzeba mówić o Jezusie jako narodzonym „ex Maria”, a nie „per Mariam"13. Na przyjęcie przez Logos pełnej natury ludzkiej wskazuje również używanie przez naszego Aleksandryjczyka na określenie tajemnicy wcielenia,

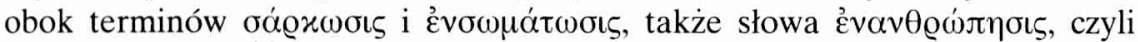

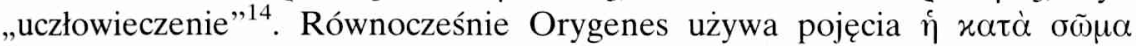

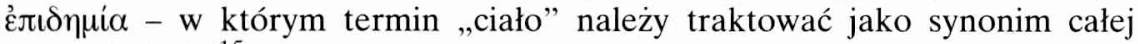
natury ludzkiej ${ }^{15}$.

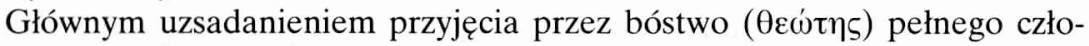

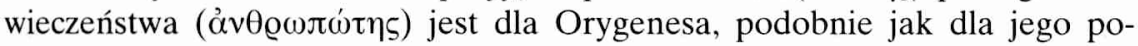
przedników, argument soteriologiczny: wymagało tego zbawienie i udoskonalenie człowieka, polegające na jego upodobnieniu do Boga. W Contra Celsum czytamy:

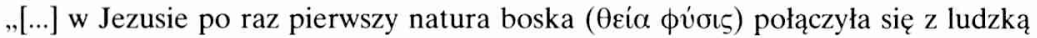

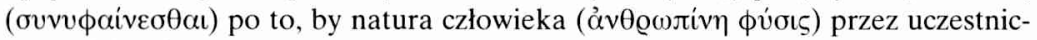
two w bóstwie stała się boska nie tylko w samym Jezusie, lecz również we wszystkich z wiarą przyjmujących sposób życia, którego nauczył Jezus [...]”"16.

Natomiast w Dialogu z Heraklidesem znajdujemy po raz pierwszy tak jasno wyrażoną zasadę, często później powtarzaną w teologii patrystycznej:

${ }^{11}$ De principiis II 6, 1. 2, SCh 252, 175.176.

12 Por. Homiliae in Ezechielem 1, 4, SCh 352, 58-60, ŹMT 16, 81; Homiliae in Lucam 17, 4, SCh 87, 254, PSP 36, 79.

${ }^{13}$ Por. Fragmenta ex Commentario in Galatas, PG 14, 1298 A; zob. także Homiliae in Exodum 12, 4, SCh 321, 366, PSP 31/1, 267; M. Fédou, dz. cyt., s. 145.

${ }^{14}$ Por. Contra Celsum III 14, SCh 136, 38, thum. S. Kalinkowski s. 148.

15 Por. Fédou s. 136.

${ }^{16}$ Contra Celsum III 28, SCh 136, 68, thum. S. Kalinkowski s. 155; por. Homiliae in Ezechielem 1, 10, SCh 352, 76, ŹMT 16, 86-87; Homiliae in Ieremiam 7, 3, SCh 232, 350, PSP 30, 70. 
„Człowiek nie zostałby w pełni zbawiony, gdyby [Zbawiciel] nie przybrał pełnego

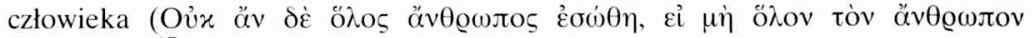

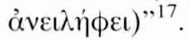

Orygenes uzupełnia powyższe stwierdzenie bardzo istotnym komentarzem, który osadza soteriologiczną argumentację wcielenia we właściwej perspektywie. Przyjęcie pełnej natury ludzkiej było niezbędne dla zbawienia człowieka, co nie oznacza, że było ono konieczne i potrzebne samemu Bogu, gdyż takie przekonanie oznaczałoby, że Bóg jest zdeterminowany sytuacją i wolą człowieka. Aleksandryjczyk wyraźnie podkreśla, że Chrystus zstąpił na ziemię zupełnie dobrowolnie ${ }^{18}$. Zadecydowała o tym Jego miłość do człowieka ( $\phi i \lambda \alpha-$ $v \theta \varrho \omega \pi i \alpha)^{19}$. Ostateczny wniosek Orygenesa jest więc następujący: Chrystus dobrowolnie przyjął pełną naturę ludzką dla zbawienia ludzkości, ponieważ

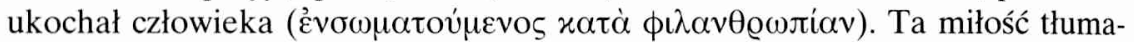
czy prawdziwe cierpienia Chrystusa na krzyżu, będące najlepszym przykładem dzielenia przez Niego w pełni życia z ludźmi ${ }^{20}$.

Obecnie przyjrzymy się co, zdaniem Orygenesa, składa się na pełną naturę każdego człowieka, którą przyjął również Logos schodząc na ziemię.

2. Trychotomiczna antropologia duchowa: duch - dusza - ciało. Kluczowy tekst Orygenesa, dotyczący interesującego nas zagadnienia struktury natury ludzkiej Chrystusa znajduje się w dziełku Dialog z Heraklidesem. Ukazuje on identyczność tej natury z tą, jaką posiada każdy człowiek, a tym samym wskazuje na zależność Orygenesowej teologii wcielenia od przyjętej przez niego koncepcji antropologii:

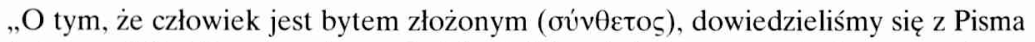
świętego. Mówi bowiem Apostoł: «Niech Bóg uświęci waszego ducha, waszą duszę i wasze ciało» (1 Tes 5,23), a także: «Niech uświęci was w całości i niech całe wasze istnienie - duch, dusza i ciało - pozostaną nienaruszone na przyjście naszego Pana Jezusa Chrystusa» $(\mathrm{Rz} 8,16)$. [...] Tak więc nasz Zbawiciel i Pan [...] zechciał [...] zbawić ciało, tak jak zechciał równocześnie zbawić duszę i jak zechciał także zbawić to, co zostało w człowieku, czyli ducha"21.

Zaprezentowany przez Orygenesa w powyższym tekście model antropologiczny, którego reminiscencje występują w innych jego dziełach: Komentarzu

${ }^{17}$ Disputatio cum Heracleida 7, SCh 67, 71, por. thum. A. Zajkowski, STV 5(1967) z. 2, 129 180, spec. 156.

18 Por. Homiliae in Numeros 27, 3, PG 12, 783-784, PSP 34, 267-268.

19 Por. Commentarius in Ioannem II 31, 187, SCh 120, 332, PSP 28/1, 137; zob. także, Homiliae in Ieremiam 1, 8, SCh 232, 212-214, PSP 30, 29; tamże, 10, 7, SCh 232, 410-413, PSP 30, 90; Commentarius in Canticum canticorum I 4, 4-5, SCh 375, 222.

${ }^{20}$ Por. Homiliae in Ezechielem 6, 6, SCh 352, 228-230, ŹMT 16, 140.

21 Disputatio cum Heracleida 6-7, SCh 67, 68-70. 
do Ewangelii Mateusza $a^{22}$, Homiliach o Księdze Ezechiela ${ }^{23}$, Komentarzu do Listu św. Pawła do Rzymian ${ }^{24}$, a przede wszystkim w traktacie $O$ zasadach $^{25}$, został określony przez współczesnych badaczy - J. Dupuisa ${ }^{26}$ i H. Crouzela ${ }^{27}$ mianem trychotomicznej antropologii duchowej. Aleksandryjczyk wyprowadził ją, podobnie jak wcześniej Ireneusz ${ }^{28}$, z biblijnych tekstów Pawłowych (1 Tes 5, 23 i Rz 8, 16).

Duch ( $\pi v \varepsilon \tilde{v} \mu \alpha$, spiritus) jest, według naszego autora, pierwiastkiem boskim w człowiéku, nie jest jednak tożsamy z Duchem Świętym. Czyni natomiast człowieka zdolnym do odbierania natchnień Ducha Świętego, kształci go w poznaniu Boga i w modlitwie, jest ośrodkiem sumienia i prowadzi duszę do doskonałości w cnocie. Duch nie ponosi odpowiedzialności za grzechy i po ich popełnieniu nie opuszcza człowieka. Pozostaje wtedy w stanie odrętwienia, jest jednak zawsze gotowy doprowadzić człowieka do nawrócenia.

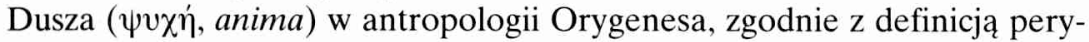
patetycką, stanowi substancję poznającą w sposób rozumny i poruszającą się $\left(\phi \alpha v \tau \alpha \sigma \tau \iota x \eta \dot{~ i ~ o ́ \varrho \mu \eta \tau \iota x \eta ́) ~}{ }^{29}\right.$. Jest ona siedzibą wolnej woli i decyduje o osobowości człowieka. W preegzystencji była tożsama z umysłem (voũs), czyli

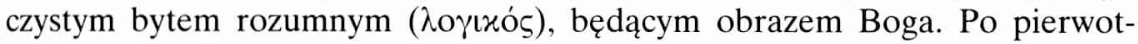
nym upadku, który łączył się - według jednej z hipotez Orygenesa - z oziębieniem lepszego boskiego stanu, dołączył do umysłu element niższy duszy,

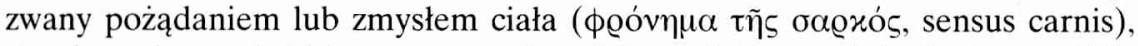
starający się przejąć kierowniczą rolę, odciągnąć duszę od ducha i uczynić ją cielesną. To pożądanie ciała ma jednak, według Orygenesa, nie tylko znaczenie pokusy, ale obejmuje również funkcje naturalne organizmu, które same w sobie nie są złe i dają się uduchowić, gdy umysł podporządkowuje się duchowi. Według domniemań Aleksandryjczyka, po dostąpieniu zbawienia, nazywanego wyzwoleniem z zagłady bądź odnowieniem i poprawą, dusza może ponownie wrócić do stanu doskonalszej cząstki, czyli rozumu (voũs,

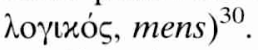

Ciało ( $\sigma \tilde{\omega} \mu \alpha$, corpus) jest, w ujęciu naszego Aleksandryjczyka, trzecim istotnym elementem składowym natury ludzkiej. Stanowi ono cechę charakte-

${ }^{22}$ Por. Commentarius in Matthaeum 13, 2, PC 13, 1092-1100, ŹMT 10, 158-160.

${ }^{23}$ Por. Homiliae in Ezechielem 1, 16, SCh 352, 94-96, ŹMT 16, 93.

24 Por. Commentarius in Romanos 1, 10, PG 12, 855-856, PSP 57, 65.

${ }^{25}$ Por. De principiis II 8, 4, SCh 252, 348, ŹMT 1, 192.

${ }^{26}$ Por. J. Dupuis, L'anthropologie d'Origène dans la perspective du combat spirituel, RAM 31(1955)364-385; tenże, L'esprit de l'homme. Étude sur l'anthropologie religieuse d'Origène, Bruges 1967.

${ }^{27}$ Por. H. Crouzel, Orygenes, thum. z franc. J. Margański, Bydgoszcz 1996, 131-145.

${ }^{28}$ Por. V 6, 1; V 9, 1; zob. G. Langemeyer, Antropologia teologiczna, Kraków 2000, s. 90.

29 Por. De principiis II 8, 1-2, SCh 252, 336-340, ŹMT 1, 187-189; zob. Aristoteles, De anima III 9, 432a 15-17.

${ }^{30}$ Por. De principiis II 8, 3, SCh 252, 342, ŹMT 1, 189-190. 
rystyczną całego stworzenia, gdyż tylko Trójca Święta jest całkowicie pozbawiona ciała. Dusze preegzystujące również posiadały ciało, ale subtelniejsze eteryczne. Po upadku otrzymało ono nową doczesną jakość. Orygenes nazywa

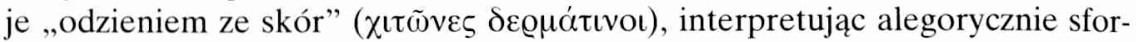
mułowanie zaczerpnięte z Rdz 3, 21. Podkreśla równocześnie, że i ten rodzaj ciała, mimo pewnej ociężałości ( $\pi \alpha \chi v \dot{\tau} \eta \varsigma)$, jest sam w sobie dobry, jako stworzony przez Boga. Preegzystujące ciało eteryczne po upadku bytuje w ciele

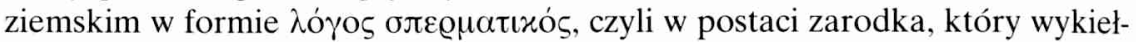
kuje po zmartwychwstaniu, zmieniając jakość ciała doczesnego ponownie na niebiańską ${ }^{31}$.

Przedstawiona wyżej w zarysie Orygenesowa antropologia trychotomiczna nosi miano duchowej, ponieważ główną zasadą, jaka nią kieruje, jest walka duchowa. Dusza wyposażona w wolną wolę musi podczas ziemskiego życia człowieka wybrać uzależnienie bądź od ducha bądź od ziemskiego ciała. Przyjrzymy się obecnie w szczegółach nauce Orygenesa na temat ducha, duszy i ciała Chrystusa. Charakteryzując te elementy postaram się ukazać, czy różniły się one w jakiś sposób od natury ludzkiej zwykłego człowieka oraz jakie funkcje spełniały w Osobie Zbawiciela.

3. Duch jako naczelny element natury ludzkiej Chrystusa. W De principiis Orygenes wyraźnie odróżnia ducha Chrystusa od Jego duszy ${ }^{32}$, natomiast we wspomnianym wyżej tekście z Dialogu z Heraklidesem podkreśla, że Jezus, chcąc zbawić ducha, który jest w człowieku, przyjął go również na siebie ${ }^{33}$. Nieco dziwne może wydawać się, że, według Orygenesa, odkupienia potrzebuje także ten element w człowieku, który jest, jak mówi sam Aleksandryjczyk, darem Boga i głosem sumienia, wolnym od odpowiedzialności za grzechy. Jednak, jak już wspomniałem, duch ludzki, choć sam nie grzeszy, zostaje zagłuszony przez grzech i wchodzi w stan otępienia. Duch Chrystusa natomiast, w przeciwieństwie do ducha człowieka po grzechu, panuje nad Jego duszą i ciałem. Nie wchodzi w stan uśpienia, ponieważ Chrystus grzechów nie popełnia. Tylko do ducha w Osobie Zbawiciela można, jak mówi Orygenes, w pełni odnieść ewangeliczne sformułowanie - „ochoczy duch” (spiritus promptus - por. Mt 26, 41$)^{34}$.

Aleksandryjczyk, podobnie jak w odniesieniu do każdego człowieka, również w przypadku natury ludzkiej Chrystusa zdecydowanie oddziela ducha, będącego składnikiem tej natury, od Ducha Świętego, mimo że oba pozostają ze sobą w ścisłej łączności:

\footnotetext{
31 Por. Crouzel, Orygenes s. 131-137.

32 Por. De principiis II 8, 4, SCh 252, 348, ŹMT 1, 192.

33 Por. Disputatio cum Heracleida 7, SCh 67, 70.

34 Por. przypis nr 32.
} 
„Ten duch nie jest Duchem Świętym, ale częścią składową człowieka ( $\mu \varepsilon \dot{g o s} \tau \tilde{\eta} \varsigma$

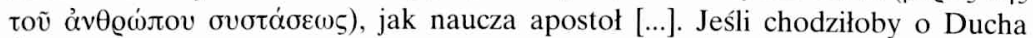
Świętego, nie powiedziałby: «Duch daje świadectwo naszemu duchowi» (por. 1 Kor 2, 11; 1 Tes 5, 23)"35.

O bliskim związku ludzkiego ducha Jezusa z Bogiem Ojcem świadczy to, co dzieje się z nim po męce Zbawiciela. Orygenes uważa, że w momencie śmierci Chrystusa nastąpiło rozdzielenie trzech elementów Jego ludzkiej natury. Ciało pozostało w grobie, dusza zstąpiła do otchłani, a duch jako najbardziej wzniosła cząstka człowieczeństwa został złożony w ręce Ojca w formie depozytu $(\pi \alpha \varrho \alpha x \alpha \tau \alpha \theta \dot{\eta} \varkappa \eta)$. Został on odzyskany nie w samym momencie zmartwychwstania, ale bezpośrednio po nim. Nasz autor uzasadnia swoje przekonanie oryginalną interpretacją fragmentu Ewangelii św. Jana 20, 17:

„Pan Jezus Chrystus powstał z martwych, zbliżyła się do Niego Maria, a On jej powiedzial: «Nie dotykaj Mnie». Pragnął bowiem, aby każdy, kto Go dotknie,

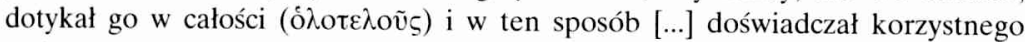
wpływu Jego ciała na swoje ciało, Jego duszy na swoją duszę, Jego ducha na swojego ducha. "Jeszcze bowiem nie wstąpiłem do Ojca». Wstępuje [więc] do Ojca i idzie do swoich uczniów. W jakim celu wstępuje do Ojca? Aby odebrać swój depozyt [czyli ducha]"36.

W świetle powyższych wypowiedzi można stwierdzić, że duch jawi się w koncepcji Orygenesa jako trudny do precyzyjnego określenia, specyficzny element natury ludzkiej Chrystusa. Należy on jakby do dwóch porządków. Stanowi zarówno pierwiastek boski, jak i nieodzowną cząstkę człowieczeństwa.

\section{Dusza Chrystusa i jej funkcja pośrednicząca między Boską a ludzką} naturą Zbawiciela. Szósty rozdział II księgi De principiis, zatytułowany „O wcieleniu Chrystusa”, jest poświęcony przede wszystkim duszy Zbawiciela. Orygenes stwierdza w nim $\mathrm{z}$ naciskiem:

,[...] w Chrystusie tkwila dusza rozumna (anima rationabilis) [...] dusza ta miała naturę wspólną ze wszystkimi duszami; gdyby bowiem nie była prawdziwą duszą, nie mogłaby nosić nazwy duszy"37.

Mimo tej wspólnoty natury dusza Chrystusa przewyższała doskonałością wszystkie pozostałe. Aleksandryjczyk kontynuuje:

„[...] słowa: «Namaścił cię Bóg, Bóg twój, olejkiem wesela bardziej niż współuczestników twoich» (Ps 45/44, 8), wskazują, iż owa dusza inaczej jest namaszczana «olejkiem wesela», czyli Słowem Bożym i Mądrością, niźli jej «współuczestnicy»,

${ }^{35}$ Disputatio cum Heracleida 6, SCh 67, 70.

36 Tamże, 8, SCh 67, 72.

${ }^{37}$ De principiis II 6, 5, SCh 252, 318, ŹMT 1, 179. 
to znaczy święci prorocy i apostołowie: oni bowiem «biegli w woni Jego pachnideł» (Pnp 1, 3), natomiast dusza Chrystusa była naczyniem samego pachnidła (vasculum unguenti ipsius) $[\ldots]^{, 38}$.

Według Orygenesa dusza, a ściśle rzecz biorąc jej wyższa, rozumna część

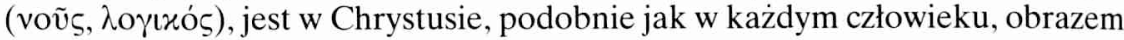
Boga. Aleksandryjczyk używa tu jednak nieco innej, bardziej skomplikowanej terminologii, bo i samo zjawisko Osoby Chrystusa jest bardziej złożone, niż w przypadku zwykłego cżłowieka. Otóż pełnym i jedynym w swoim rodzaju „obrazem Boga” jest Boski Logos. Każda ludzka dusza jest więc właściwie „obrazem obrazu”, ponieważ została stworzona na obraz Boży, czyli za pośrednictwem Logosu. W Osobie Chrystusa dochodzi do ścisłego złączenia obrazu Boga, jakim jest Logos, z obrazem tego obrazu, jakim jest ludzka dusza Jezusa. Aby uniknąć zamieszania pojęciowego, a także aby podkreślić, że dusza ta jest ściśle złączona ontycznie i moralnie z Logosem, Orygenes nazywa ją „cieniem” (бxi $\alpha$, umbra) Logosu, czyli Boskiej natury Zbawiciela. Cień bowiem ściślej łączy się z daną rzeczywistością niż jej obraz. Nasz autor, przeprowadzając swój wywód, posługuje się, jak to ma w zwyczaju, alegoryczną interpretacją fragmentu Pisma świętego:

,[...] prorok Jeremiasz [...] powiedział [...] tak: «Mesjasz Pan tchnieniem oblicza naszego»; mówiliśmy o Nim: «W Jego cieniu będziemy żyć wśród narodów» (Lm 4, 20). Wydaje mi się, że prorok chciał wskazać tu na uczynki i poruszenia duszy Chrystusowej, która nierozerwalnie związała się z Chrystusem i wypełniła wszystko stosownie do Jego zamierzeń i woli, podobnie jak nasz cień nieodłączny od ciała nieodmiennie przybiera i naśladuje ruchy i gesty ciała; duszę tę nazwał «cieniem» (umbra) Mesjasza Pana, w którym to cieniu «żyjemy wśród narodów»"39.

Wobec faktu tak wielkiej doskonałości duszy Chrystusa można zapytać, czy Orygenes przypisywał jej także niższą część, zwaną dążnością ciała. Otóż Aleksandryjczyk uznawał istnienie tego elementu w duszy Jezusa, jednak w związku z bezgrzesznością Chrystusa niższa część Jego duszy nie mogłą być dla niego źródłem pokusy. Stanowiła więc jedynie źródło takich uczuć jak: niepokój, smutek i cierpienie ${ }^{40}$.

Orygenes, przyjmując platonizującą hipotezę preegzystencji dusz, uzależniał ziemską kondycję człowieka od jego własnej wcześniejszej decyzji podjętej w świecie dusz przed przyjęciem ziemskich ciał. Włączenie duszy Chrystusa w tę koncepcję pozwoliło naszemu autorowi na rozwiązanie istotnych problemów. Po pierwsze - orygenesowski pogląd o preegzystencji duszy Chrystusa i złącze-

\footnotetext{
38 Tamże, II 6, 6, SCh 252, 320-322. ŹMT 1, 179-180.

39 Tamże, II 6, 7, SCh 252, 324, ŹMT 1, 181

${ }^{40}$ Por. H. Crouzel, Orygenes s. 134.
} 
niu jej z Boskim Logosem już przed wejściem w ludzkie ciało pozwolił widzieć w duszy element pośredniczący między tym, co Boskie, duchowe, transcendentne, niezmienne i nieśmiertelne, a tym, co ludzkie, cielesne, immanentne oraz podlegające zmianom, cierpieniu i wreszcie śmierci. W De principiis czytamy:

„Substancja tej duszy [Chrystusa - przyp. M.S.] pośredniczy więc między Bogiem a ciałem (inter deum carnemque mediante), ponieważ bez pośredniczącego ogniwa istota bóstwa nie mogła się z ciałem związać; dzięki temu narodził się [...] Bógczłowiek. Owa pośrednia substancja miała bowiem taką naturę, że mogła przybrać ciało; z drugiej strony dusza ta, będąc substancją rozumną, z natury swojej mogła również przyjąć do siebie Boga"41.

Po drugie teoria preegzystencji duszy Chrystusa umożliwiła Orygenesowi wyjaśnienie kwestii bezwzględnego posłuszeństwa natury ludzkiej wobec Boskiej w Osobie Chrystusa i wynikającej stąd Jego bezgrzeszności jako człowieka, przy równoczesnym zachowaniu przez Jezusa wolnej woli. Według Aleksandryjczyka dusza Chrystusa od początku, jeszcze jako czysty byt rozumny (voṽ $\lambda$ ơıนós), była jako jedyna ściśle zespolona z Boskim Logosem. Nasz autor określa ten związek obrazowym, niezbyt szczęśliwym porównaniem, które mogło później budzić podejrzenie o jakąś pierwotną formę monofizytyz$\mathrm{mu}^{42}$. Orygenes pisze:

„Oto [...] jeśli [...] określony kawałek żelaza bez przerwy leży w ogniu [...], to zgodnie z prawdą powiemy [...], że zupełnie przemienił się on $w$ ogień - jak to możemy często oglądać w piecach hutniczych - bo nie dostrzegamy w nim nic poza ogniem, a jeśli kto spróbuje go dotknąć i pomacać, to poczuje wartość fizyczną nie żelaza, ale ognia. Podobnie jest z duszą Chrystusa, która niczym żelazo w ogniu zawsze tkwi w Słowie, w Mądrości i w Bogu; we wszystkim, co robi, co czuje i co myśli, jest Bogiem"43.

Autor De principiis jest jednak daleki od ograniczania w jakikolwiek sposób pełni ludzkiego wymiaru duszy Chrystusa. Podkreśla, że tak jak wszystkie dusze ludzkie została ona obdarzona wolną wolą i w wyniku własnej decyzji opowiedziała się całkowicie za Bogiem, zyskując substancjalną bezgrzeszność i wolność od pierwotnego upadku:

„Chociaż jednak wszystkie dusze istotnie posiadają zdolność wyboru między dobrem a złem, to przecież dusza Chrystusowa tak stanowczo wybrała «umiłowanie

${ }^{41}$ De principiis II 6, 3, SCh 252, 314-316, ŹMT 1, 177.

42 Por. Fédou s. 162.

43 De principiis II 6, 6, SCh 252, 320: „Hoc ergo modo etiam illa anima, quae quasi ferrum in igne sic semper in verbo, semper in sapientia, semper in deo posita est, omne quod agit, quod sentit, quod intelligit, Deus est”, przekład zob. ŹMT 1, 179. 
sprawiedliwości», iż dzięki temu ogromnemu umiłowaniu związała się z nią nierozerwalnie i trwale, wskutek czego mocne postanowienie, niezmierzone uczucie i niezniszczalny żar miłości wykluczyły wszelką myśl o odwrocie i zmianie; to więc, co zależało od jej woli, wskutek długotrwałego działania afektu stało się jej naturą"44.

Powyższe stanowisko było wprawdzie próbą rozwiązania problemu pogodzenia bezgrzeszności Chrystusa jako człowieka z Jego wolną wolą, ale równocześnie stwarzało istotne zagrożenie dla pojmowania wcielenia jako bezinteresownego daru od Boga. Orygenes uważał bowiem, że

,[...] źródłem trwałego związku owej duszy z Bogiem była doskonała miłość oraz szczere i czyste uczucie, że Bóg przyjął ją do siebie dzięki jej cnotom, a nie przypadkowo $[\ldots], 45$.

Z powyższego stwierdzenia Aleksandryjczyka wynika, że zasługa duszy Jezusa poprzedza wcielenie. Słusznie więc ks. Woliński stwierdza, że „nie znajdujemy się tu już w nurcie tradycji chrześcijańskiej i rozważania te nie zostaną podjęte przez późniejszą teologię"46.

\section{Prawdziwe ciało Chrystusa zasłaniające i ujawniające Jego Bóstwo.} Orygenes wielokrotnie przypomina, że ciało stanowi niezbędny element natury ludzkiej Chrystusa ${ }^{47}$. Chociaż podkreśla przeciw ebionitom i Celsusowi, że Chrystus nie narodził się z mężczyzny i kobiety ${ }^{48}$, ale z Dziewicy i Ducha Świętego ${ }^{49}$, choć zdaje się także nawiązywać do poglądów greckich fizjonomistów, uznających, że wygląd ciała musi być dostosowany do charakteru duszy $^{50}$, to równocześnie $\mathrm{z}$ naciskiem stwierdza przeciw doketom, że Jezus przyjął ciało podobne do naszego ciała, narodził się, cierpiał i umierał jak

${ }^{44}$ Tamże, II 6, 5, SCh 252, 320: „Verum quoniam boni malique eligendi facultas omnibus praesto est, haec anima, quae Christi est, ita elegit diligere iustitiam, ut pro immensitate dilectionis inconvertibiliter ei atque inseparabiliter inhaereret, ita ut propositi firmitas et affectus inmensitas et dilectionis inextinguibilis calor omnem sensum conversionis atque immutationis adscideret, ut quod in arbitrio erat positum, longi usus affectu iam versum sit in naturam”, przekład zob. ŹMT 1, 179.

45 Tamże, II 6, 4, SCh 252, 316: „Quod autem dilectionis perfectio et meri affectus sinceritas hanc ei inseparabilem cum deo fecerit unitatem, ita ut non fortuita fuerit [...] animae eius assumptio, sed virtutum suarum ei merito delata [...]", przekład zob. ŹMT 1, 178; por. tamże, IV 4, 4, SCh 268, 408-412, ŹMT 1, 382-383.

${ }^{46}$ B. Sesboüe - J. Woliński, Historia dogmatów, t. 1: Bóg zbawienia, thum. z franc. P. Rak, Kraków 1999, 202.

${ }^{47}$ Por. De principiis praef. 4, SCh 252, 80-82, ŹMT 1, 53; tamże, II 6, 3, SCh 252, 314-316, ŹMT 1, 177; Commentarius in Ioannem XXXII 16, 191, SCh 385, 269, PSP 28/2, 151; tenże, Disputatio cum Heracleida 6-7, SCh 67, 68-72.

48 Por. Homiliae in Lucam 17, 4, SCh 87, 254, PSP 36, 79.

${ }^{49}$ Por. De principiis, praef. 4, SCh 252, 80, ŹMT 1, 53.

${ }^{50}$ Por. Contra Celsum I 33, SCh 132, 166, thum. S. Kalinkowski, 58-59. 
każdy człowiek ${ }^{51}$. Jego ciało nie było zbudowane $\mathrm{z}$ pierwiastków niebieskich i duchowych, jak fałszywie twierdzili Marcjon i Apelles, ale było zwykłym ludzkim ciałem. W nawiązaniu do słów proroka Zachariasza 3, 3, przedstawiających Jozuego ubranego w brudne szaty, Aleksandryjczyk stwierdza, że również Jezus, którego Jozue był typem, do tego stopnia uniżył się dla zbawienia człowieka, że $\mathrm{z}$ własnej woli przyjął ciało ziemskie $\mathrm{w}$ jego pełnej materialności, związanej $\mathrm{z}$ pewnym rodzajem brudu (sors), wynikającym z urodzenia. Właśnie dlatego, że Zbawiciel był ubrany w brudne szaty, czyli przyjął ziemskie ciało, trzeba było złożyć za Niego ofiary, które zgodnie ze zwyczajem Prawa oczyszczały z brudu. Orygenes ostrzega przy tym, by nie utożsamiać brudu cielesnego z grzechem, od którego Chrystus był wolny ${ }^{52}$.

Chociaż nasz autor nigdzie w zachowanych dziełach nie mówi o tym wprost, zapewne przypisuje Jezusowi ciało eteryczne w preegzystencji, zgodnie z przekonaniem, że tylko natura Trójcy Św. jest bezcielesna. Po zmartwychwstaniu i wniebowstąpieniu, ziemskie brudne i ociężałe ciało Jezusa, mimo że zacho-

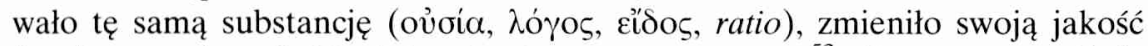

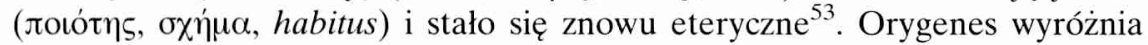
jeszcze okres przejściowy między zmartwychwstaniem i wniebowstąpieniem, kiedy Jezus ukazywał się swoim uczniom jakby na granicy pomiędzy ociężałością ciała, jakie miał przed męką, a stanem, w którym dusza pojawia się wyzwolona od takiego ciała ${ }^{54}$. Pozwalał się dotykać i pokazywał im swoje rany, a więc miał ,ciało masywne i dotykalne” (corpus solidum et palpabi$l e)^{55}$, ale także przechodził przez zamknięte drzwi.

Nauka Orygenesa o ciele Chrystusa, poza związkiem z hipotezą preegzystencji, i mimo nie zawsze precyzyjnego języka, w jakim została sformułowana, jest w zasadniczych punktach wyczerpująca i zgodna z późniejszą ortodoksją. Crouzel dowiódł, że Metody z Olimpu nie zrozumiał Aleksandryjczyka, twierdząc, że, jego zdaniem, ciało chwały Chrystusa i wszystkich ludzi jest zupełnie czym innym niż ciało ziemskie. Zniekształcają myśl Orygenesa również zarzuty Metodego, Hieronima i cesarza Justyniana jakoby Aleksandryjczyk przyjmował kulisty, czyli doskonały kształt ciała uwielbionego oraz pozbawiał go narządów płciowych jako zbytecznych w nowym świecie ${ }^{56}$. Przykładem współczesnego niezrozumienia poglądów Orygenesa na temat ciała Chrystusa, wynikającego z pomieszania tego, co Aleksandryjczyk mówi o ciele ziemskim i uwielbionym, jest fragment rozdziału o chrystologii aleksandryjskiej w słyn-

${ }^{51}$ Por. Homiliae in Ezechielem 1, 4, SCh 352, 58-60, ŹMT 16, 81; tenże, Homiliae in Lucam 17, 4, SCh 87, 254, PSP 36, 79.

52 Por. Homiliae in Lucam 14, 3-5, SCh 87, 218-222, PSP 36, 68-69.

53 Por. Contra Celsum III 41-42, SCh 136, 94-100, thum. S. Kalinkowski, s. 161-162.

${ }^{54}$ Por. tamże, II 62, SCh 132, 428-430, tłum. S. Kalinkowski, s. 127-128.

55 Por. De principiis, praef. 8, SCh 252, 86, ŹMT 1, 55-56.

56 Por. Crouzel, Orygenes, s. 335-336, 340. 
nej, ale niestety miejscami przestarzałej książce J.N.D. Kellyego Początki doktryny chrześcijańskiej ${ }^{57}$.

Jeśli chodzi o zadania, jakie miało spełnić przyjęcie cielesności przez Chrystusa, to oprócz funkcji zbawczej wobec ludzkiego ciała, odegrało ono, według Orygenesa, rolę związaną z objawieniem ludziom Jego boskości. Syn Boży stał się taki, jak człowiek, aby dać się poznać za pośrednictwem zmysłów, na sposób ludzki. Aleksandryjczyk zwraca jednak uwagę, że przy całej swej realności ciało Zbawiciela jest równocześnie jedynie zasłoną przybytku, jakim jest Jego Boska natura $^{58}$, a wcielenie nie przynosi czystej i pełnej wizji boskości, ale pozwala zobaczyć tylko jej odblask ${ }^{59}$. Aby więc poznać Syna Bożego, należy uruchomić zmysły duchowe, umożliwiające dostrzeżenie tego, co ukrywa się pod powłoką cielesną, a pełne poznanie natury Boskiej Chrystusa stanie się możliwe po zmartwychwstaniu, kiedy człowiek zrzuci „odzienie ze skór”, czyli ociężałą jakość ziemskiego ciała.

Nauka Orygenesa o pełnym człowieczeństwie Chrystusa wpisuje się w nurt wczesnochrześcijańskiej teologii poszukiwania ze wszystkimi swoimi zaletami i wadami. Do tych pierwszych należy niewątpliwie zaliczyć: ukazanie integralności natury ludzkiej Zbawiciela, uzasadnienie jej za pomocą argumentu soteriologicznego osadzonego w bezinteresownej miłości Boga, zwrócenie uwagi na istotną rolę duszy jako mediatora między Boskim Logosem a ludzkim ciałem oraz podkreślenie prawdziwej cielesności Chrystusa przeciw wszelkim prądom doketystycznym i gnostyckim. Pewne trudności sprawiało naszemu autorowi jasne zdefiniowanie ,ducha”, określanego równocześnie jako pierwiastek boski i element natury ludzkiej. Również teologowie wczesnochrześcijańscy po Orygenesie nie bardzo umieli sobie poradzić z elementem „ducha” w antropologii i chrystologii. Jedni utożsamiali go z Duchem Świętym, jak np. Grzegorz z Nyssy, inni, jak Ewagriusz z Pontu, uznali go za odpowiednik , $\psi v \chi \grave{\eta}$

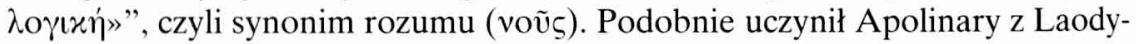
cei, wyciągając $z$ tego najdalej idące wnioski. W jego doktrynie redukującej naturę ludzką Chrystusa do ciała i ewentualnie duszy biologicznej ( $\psi v \chi \grave{\eta})$, miejsce ducha ludzkiego, rozumianego jako „voũs”, zajmie w osobie Chrystusa Boski Logos.

Ze słusznym sprzeciwem spotkała się zakorzeniona w micie platońskim orygenesowska hipoteza preegzystencji dusz ludzkich w ogóle, a duszy Chrys-

${ }^{57}$ Por. Początki doktryny chrześcijańskiej, thum. z ang. J. Mrukówna, Warszawa 1988, 124.

58 Por. Homiliae in Exodum 9, 1, SCh 321, 280, PSP 31/1, 238-239.

59 Por. Homiliae in Iesu Nave 3, 5, SCh 71, 144, PSP 34/2, 21. 
tusa w szczególności, ale należy pamiętać, że wprowadzenie tej hipotezy na ówczesnym etapie rozwoju teologii pozwalało Orygenesowi polemizować z gnostyckim determinizmem w odniesieniu do natury ludzkiej, a także tłumaczyć, choć nieudolnie, ścisłe zjednoczenie diametralnie różniących się od siebie natur - Boskiej i ludzkiej - w osobie Chrystusa. Wrogość wobec orygenesowskiej doktryny o preegzystencji dusz pociągnęła za sobą niestety również niechęć do przypisywania istotnej roli ludzkiej duszy w osobie Chrystusa, jako rzekomego zagrożenia jedności tej osoby. Obowiązujący w chrystologii stał się aż do czasów Apolinarego z Laodycei model „Logos-sarx”, ograniczający człowieczeństwo Chrystusa do samego ciała. Pogląd ten łączył nawet tak wielkich adwersarzy, jak Ariusz i Atanazy. Gdy Ojcowie Kapadoccy starali się przywrócić duszy należne miejsce w ludzkiej naturze Chrystusa niewątpliwie nawiązywali do poglądów autora De principiis.

Orygenes nie rościł sobie pretensji do podania wyczerpującego i doskonałego wykładu dotyczącego wcielenia. Uważał, że przerasta to jego możliwości z racji wyjątkowości samego zjawiska, jak i z ograniczenia ludzkiego poznania, a także $z$ powodu znajdowania się teologii zaledwie $w$ początkowym stadium rozwoju. Wypowiedź, którą zakończę ten artykuł, jest świadectwem posiadania przez Orygenesa, obok intelektualnego geniuszu i głębokiej wiary, także dwóch cech niezbędnych dla każdego prawdziwego teologa: pokory i zdolności nieustannego dziwienia się. Oto, co trochę retorycznie, ale niewątpliwie szczerze, stwierdza nasz autor w VI rozdziale II księgi De principiis dotyczącym wcielenia Chrystusa:

„Gdy [...] dostrzegamy w Chrystusie pewne cechy ludzkie do tego stopnia, że nie różnią się one niczym od niedoskonałości wspólnej wszystkim śmiertelnikom, a z drugiej strony widzimy w Nim pewne właściwości boskie, które przysługują jedynie pierwotnemu i niewysłowionemu Bóstwu, wówczas rozum ludzki ogarnia takie zaskoczenie i zdziwienie (angustia et [...] ammirationis stupor), iż człowiek nie wie, gdzie ma się zwrócić, czego ma się trzymać i dokąd się skierować. [...] Dlatego z całą bojaźnią i szacunkiem (cum omni metu et reverentia) tak powinniśmy pojmować Chrystusa, ażeby w jednej i tej samej osobie podkreślać prawdziwość obydwu natur [...]. Jeśli [...] poruszam ten temat, to nie z zuchwalstwa (non temeritate), ale dlatego, że wymaga tego tok mojej rozprawy (ordo loci poposcit) [...] są to [...] raczej moje przypuszczenia (suspiciones), niźli jakieś oczywiste stwierdzenia (adfirmationes), ${ }^{, 60}$.

${ }^{60}$ Origenes, De principiis II 6, 2, SCh 252, 312-314, ŹMT 1, 176. 


\section{L'INTEGRALITÉ DE LA NATURE HUMAINE DU CHRIST DANS LA CONCEPTION DE L'HOMME CHEZ ORIGÈNE}

(Résumé)

Origène (185-253/4) fut le premier parmi les théologiens du début de la chrétienté gui entreprit de faire une synthèse de l'enseignement sur la plénitude humaine de Jésus-Christ, sur la structure de sa nature humaine et de ses fonctions. C'était un événement dans le milieu alexandrin, attaché plutût à la contemplation de la divinité du Christ et au modèle de christologie venant d'en haut. En esquissant l'enseignement d'Origène sur la plénitude de la nature humaine de Jésus, unie étroitement avec sa nature divine, l'article fait relever le fondamental modèle trichotomique d'anthropologie (esprit - âme - corps) qui, d'après Origène, se rapporte à chaque homme, pour présenter sur ce fond la conception de la structure de l'humanité du Christ chez Origène.

Le mérite de l'enseignement d'Origène sur l'humanité du Christ est de 1) faire relever l'integralité de la nature humaine de Redempteur, 2) d'en présenter le fondement en faisant recours à l'argument sotériologique basé sur l'amour désintéressé de Dieu, 3) de faire attirer l'attention sur le rôle essentiel de l'âme en tant que médiateur entre le Logos divin et le corps humain, 4) enfin, de mettre en évidence la corporalité réelle du Christ contre tout courant docétistique et gnostique. Notre auteur avait toutefois une certaine difficulté à déterminer d'une façon claire et nette l'«esprit», défini à la fois en tant qu'un élément divin et un élément propre à la nature humaine. Les théologiens postérieurs ont objecté à juste titre à l'hypothèse d'Origène, enracinée dans le mythe platonicien, sur la préexistence des âmes humaines en général et de l'âme du Christ en particulier. 